\title{
Review \\ Campylobacter Biofilms: Potential of Natural Compounds to Disrupt Campylobacter jejuni Transmission
}

\author{
Bassam A. Elgamoudi ${ }^{1}$ (D) and Victoria Korolik $1,2, *$ (D) \\ 1 Institute for Glycomics, Griffith University, Gold Coast, QLD 4222, Australia; b.elgamoudi@griffith.edu.au \\ 2 School of Pharmacy and Medical Science, Griffith University, Gold Coast, QLD 4222, Australia \\ * Correspondence: v.korolik@griffith.edu.au
}

Citation: Elgamoudi, B.A.; Korolik, V. Campylobacter Biofilms: Potential of Natural Compounds to Disrupt Campylobacter jejuni Transmission. Int J. Mol. Sci. 2021, 22, 12159. https:// doi.org/10.3390/ijms222212159

Academic Editor: Jintae Lee

Received: 6 October 2021

Accepted: 8 November 2021

Published: 10 November 2021

Publisher's Note: MDPI stays neutral with regard to jurisdictional claims in published maps and institutional affiliations.

Copyright: (c) 2021 by the authors. Licensee MDPI, Basel, Switzerland. This article is an open access article distributed under the terms and conditions of the Creative Commons Attribution (CC BY) license (https:// creativecommons.org/licenses/by/ $4.0 /)$.

\begin{abstract}
Microbial biofilms occur naturally in many environmental niches and can be a significant reservoir of infectious microbes in zoonotically transmitted diseases such as that caused by Campylobacter jejuni, the leading cause of acute human bacterial gastroenteritis world-wide. The greatest challenge in reducing the disease caused by this organism is reducing transmission of C. jejuni to humans from poultry via the food chain. Biofilms enhance the stress tolerance and antimicrobial resistance of the microorganisms they harbor and are considered to play a crucial role for Campylobacter spp. survival and transmission to humans. Unconventional approaches to control biofilms and to improve the efficacy of currently used antibiotics are urgently needed. This review summarizes the use plant- and microorganism-derived antimicrobial and antibiofilm compounds such as essential oils, antimicrobial peptides (AMPs), polyphenolic extracts, algae extracts, probioticderived factors, D-amino acids (DAs) and glycolipid biosurfactants with potential to control biofilms formed by Campylobacter, and the suggested mechanisms of their action. Further investigation and use of such natural compounds could improve preventative and remedial strategies aimed to limit the transmission of campylobacters and other human pathogens via the food chain.
\end{abstract}

Keywords: Campylobacter; biofilm; natural compounds; antibiofilm

\section{Introduction}

Bacteria typically prefer to grow in biofilms and complex communities where they are protected from physical trauma, host immune responses, desiccation and antimicrobial agents [1-5]. In this mode, bacteria exude gelatinous exopolymeric substances that are mostly polysaccharides, proteins and DNA. Progressively, a structured biofilm matrix or a gel, containing bacteria and exuded elements, is formed. In nature, bacterial biofilms almost always consist of multiple microbial species, and are readily formed on both biotic and abiotic surfaces such as tissues, medical devices and prostheses.

Campylobacter jejuni, and its close relative Campylobacter coli, are capable of forming mono and multi-species biofilms [6], and are the most common foodborne bacterial pathogens. They are the cause of annual diarrhoeal disease for about $10 \%$ of the world's population (WHO) including 200 million children, resulting in human suffering and high economic burden $[7,8]$. The clinical features of C. jejuni gastroenteritis range from mild, non-inflammatory diarrhoea to severe abdominal cramps and febrile bloody diarrhoea that requires hospitalisation and antimicrobial chemotherapy. C. jejuni can also cause post-infection complications, including those associated with acquired immune-mediated neuropathies of the peripheral nervous system such as Guillian Barré Syndrome (GBS), resulting in neuromuscular paralysis [9]. Other complications such as meningitis, urinary tract infections and bacteraemia have also been reported [10,11].

These Campylobacter spp. can be found in water reservoirs, as commensals in the intestinal tract of animals, particularly birds, and as virulent pathogens in humans. The animal reservoirs play an important role in transmission of infectious organisms to hu- 
mans and include domestic and wild animals [12-15]. Contaminated animal food products, poultry, in particular, are considered to be a major source of bacteria causing human campylobacteriosis $[10,16]$. Campylobacter spp. are also able to survive well in the openair farm environment and can be isolated from unpasteurized milk, raw vegetables, soil and surface water $[13,17,18]$. Several potential survival mechanisms of Campylobacter spp. have been suggested, such as stationary phase survival mechanism, stress responses (i.e., thermal stress response), viable but nonculturable state (VBNC), and, of course, biofilm formation [19-23]. Biofilms have been implicated in transmission of campylobacter disease via complex mixed-species communities that form part of the natural microbiota in chicken caeca and animal intestines. Campylobacteria then persist in surface-type biofilms on animal food products and packaging $[6,14,24,25]$. Therefore, similar to other bacterial pathogens, the ability to form biofilms is an important virulence mechanism in relation to transmission of disease causing campylobacteria to humans $[1,26,27]$.

\section{Campylobacter spp. Biofilm Formation and Regulation}

The formation of biofilms significantly increases the ability of $C$. jejuni to survive in extreme conditions [28,29]. For instant, biofilm encased campylobacter cells survive twice as long under atmospheric conditions, and had been shown to form strong biofilms under aerobic condition $[15,30]$. Biofilm formation is also recognized as a potential reservoir for antimicrobial resistance and is known to facilitate exchange of resistance genes between pathogenic and commensal bacteria [31]. This is particularly pertinent in case of Campylobacter spp., including C. jejuni and C. coli, which exhibit intrinsic resistance to many antimicrobial agents and are naturally conjugative [32-34]. In addition, Campylobacter spp. are becoming increasingly resistant to the most frequently prescribed antibiotics such as erythromycin, tetracycline and fluoroquinolones, and have been listed by WHO as a priority pathogen for the development of new antibiotics [35,36]. The usage of antibiotics in food animals to control, prevent and treat infections, and to enhance growth, has been implicated in an increased resistance to multiple antibiotics by Campylobacter spp. [37]. Majority of C. jejuni and C. coli are now resistant to at least one of the currently used antibiotics, such as penicillin, trimethoprim, sulfamethoxazole, rifampicin and vancomycin [37], requiring alternative treatments with either gentamicin or third-generation cephalosporins [38].

Several studies have shown that $C$. jejuni strains are able to attach to, and form monoor mixed-species biofilms with other bacterial species such as Pseudomonas aeruginosa, Escherichia coli, Staphylococcus simulans, Enterococcus faecalis, Salmonella spp., Flavobacterium spp., and Corynebacterium spp. $[6,39,40]$. The evidence from these recent publications suggests that the composition of Campylobacter spp. biofilms is similar to that formed by other organisms. While there has been some investigation of the extracellular matrix components of $C$. jejuni biofilms, the architecture and the composition of these are yet to be fully characterized. C. jejuni NCTC strain 11168 was reported to produce an extracellular fibrelike material as a component of its biofilm, structurally resembling a net-like matrix [8]. Such matrices contribute to biofilm-mediated antimicrobial resistance, either by acting as a diffusion barrier or by binding directly to antimicrobial agents and preventing their access to the biofilm-encased cells [26]. The extracellular DNA (eDNA) is important for establishment and maintenance of $C$. jejuni biofilm [41,42], and appears to be a crucial component of the extracellular matrix of mature biofilms as degradation of eDNA results in reduction of biofilm formation by C. jejuni [41-43]. Interestingly, Gaasbeek et al. [44] found that a C. jejuni Mu-like prophage-integrated element 1 (CJIE1) containing strain, a non-naturally transformable strain, has a gene encoding an extracellular DNase (eDNase, CJE0256), and eDNase activity could be detected. It is interesting to note that no eDNase activity could be found in naturally transformable C. jejuni strains such as NCTC11168 and 81116.

Most of our current knowledge of Campylobacter spp. biofilm architecture is summarised in Figure 1. In the first stage of biofilm formation, planktonic cells attach to the surface via two types of interaction: cell-surface and cell-cell interactions using flagella, fimbriae, amyloid-like fibrils and outer membrane proteins [45-47]. This process is critical 
for bacterial adhesion and is influenced by the properties of both bacterial cells and the surface $[48,49]$. Secondly, after initial attachment, the cells start production of extracellular polymeric substance (EPS) consisting of polysaccharides, extracellular DNA (eDNA) [42], proteins [50], lipids and other glycosylated polymers, in order to initiate micro-colonies and progress to the third stage of a mature biofilm [51,52]. In a mature biofilm, EPS acts as an adhesive between cells and supports the intricate three-dimensional (3D) structure of the biofilm, protecting the cells from toxic compounds such as antibiotics, but allowing the movement of fluid and nutrients [53]. Finally, cell death and autolysis serve as a trigger for the mature biofilm to detach and release cells into the environmental niche in a process called dispersion [54]. Biofilm dispersion is believed to be crucial for the propagation and self-renewal of bacterial communities $[53,55]$ and contributes to bacterial survival, pathogenicity and most importantly, disease transmission [53,56,57].

The understanding of gene regulation of $C$. jejuni biofilm formation is still limited. There are a number of genes known to be involved in the biofilm formation process and include those responsible for motility and chemotaxis [58-60], lipooligosaccharide biosynthesis [58,59,61,62], $N$-linked protein glycosylation, capsular polysaccharides (CPS) [58,62,63], and stress response proteins. Quorum sensing (QS), which allows the bacteria to regulate population cell density in biofilms was also found to play a role in Campylobacter biofilm formation and to contribute to host colonisation $[40,60,64,65]$. However, an important messenger, the intercellular bis-( $\left.3^{\prime}-5^{\prime}\right)$-cyclic dimeric guanosine monophosphate (c-di-GMP), which plays an essential role in the transition between sessile and motile lifestyles in many other organisms [66], or its homologue, is yet to be found in the C. jejuni genome.

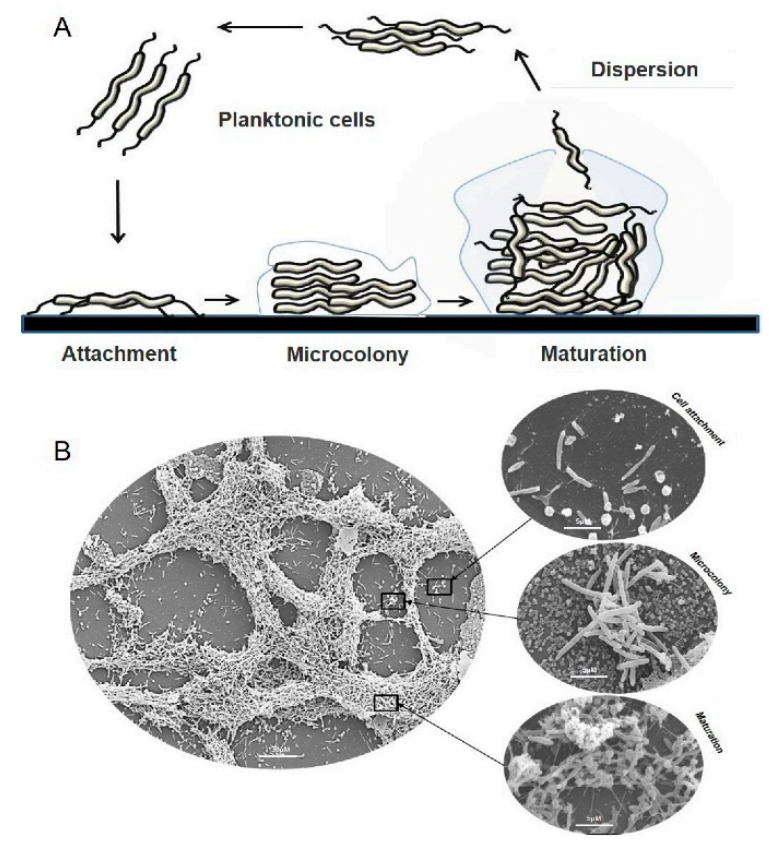

Figure 1. Cycle of biofilm development. (A) Planktonic cells swim and attach to surfaces (cell-tosurface and cell-to-cell) resulting in the formation of microcolonies. Mature biofilms can return to a planktonic lifestyle through dispersion and released seed cells complete the cycle of biofilm development. (B) Representative scanning electron microscopy (SEM) images of C. jejuni cultured under microaerobic conditions.

\section{Natural Antibiofilm Compounds}

Biofilm-disrupting and antimicrobial properties of many naturally occurring compounds against pathogens have been previously explored [67-69]. Such compounds (Table 1) include different plant extracts and their components (e.g., containing polyphenols), essential oils (e.g., containing carvacrol) and marine inhabitants (algae extracts), and a number of these have been tested against campylobacters. 
Table 1. Antibiofilm activity of natural compounds with their mechanism of action.

\begin{tabular}{|c|c|c|c|c|c|}
\hline \multicolumn{2}{|r|}{ Compounds } & Mechanism of Action & Strains & MIC* & References \\
\hline \multicolumn{6}{|c|}{ Plant-derived compounds } \\
\hline \multirow{7}{*}{$\begin{array}{l}\text { Essential oils } \\
\text { (EOs) }\end{array}$} & - $\quad$ Cinnamaldehyde & \multirow{7}{*}{$\begin{array}{l}\text { breakdown of } \\
\text { the extracellular } \\
\text { matrix } \\
\text { inhibit the } \\
\text { activity of AI-2 } \\
\text { molecules }\end{array}$} & \multirow{7}{*}{$\begin{array}{l}\text { C. jejuni NCTC } 11168 \\
\text { C. coli } \\
\text { C. jejuni S-8 } \\
\text { C. jejuni NCTC } 81-176 \\
\text { C. jejuni } \mathrm{RC} 039\end{array}$} & $1.76 \mathrm{mg} / \mathrm{L}(75.64 \mathrm{mM})$ & {$[70,71]$} \\
\hline & Clove oil & & & $0.05-0.4 \mathrm{mg} / \mathrm{mL}$ & {$[72]$} \\
\hline & Eugenol & & & $2.69 \mathrm{mg} / \mathrm{L}(60.9 \mathrm{mM})$ & [73] \\
\hline & Carvacrol & & & $31.25 \mathrm{mg} / \mathrm{L}(66.56 \mathrm{mM})$ & [74] \\
\hline & - $\quad$ Lavender essential oil & & & $1 \mathrm{mg} / \mathrm{mL}$ & {$[75]$} \\
\hline & - $\quad$ Juniper essential oil & & & $1 \mathrm{mg} / \mathrm{mL}$ & {$[74,76]$} \\
\hline & $(-)$ - $\alpha$-Pinene & & & $125 \mathrm{mg} / \mathrm{L}$ & {$[77]$} \\
\hline \multirow{7}{*}{ Plant extracts } & 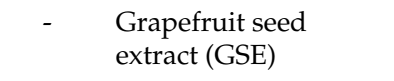 & \multirow{7}{*}{$\begin{array}{l}\text { break-down the } \\
\text { outer } \\
\text { membranes } \\
\text { inhibit the } \\
\text { activity of AI-2 } \\
\text { molecules }\end{array}$} & \multirow{7}{*}{$\begin{array}{l}\text { C. jejuni NCTC } 11168 \\
\text { C. jejuni S-8 } \\
\text { C. jejuni } \mathrm{F} 38011 \\
\text { C. jejuni 180ip } \\
\text { C. jejuni 238ip } \\
\text { C. coli }\end{array}$} & $60 \mathrm{mg} / \mathrm{L}$ & [78] \\
\hline & $\begin{array}{l}\text { - Citrus limon peel } \\
\text { extract }\end{array}$ & & & $225 \mu \mathrm{g} / \mathrm{mL}$ & [79] \\
\hline & $\begin{array}{ll}\text { - } & \text { Ethanol solution } \\
\text { extract (EREE) }\end{array}$ & & & $64-1024 \mu \mathrm{g} / \mathrm{mL}$ & {$[80]$} \\
\hline & $\begin{array}{l}\text { Green tea } \\
\text { (epigallocatechin } \\
\text { gallate) }\end{array}$ & & & $50 \mu \mathrm{g} / \mathrm{mL}$ & {$[81,82]$} \\
\hline & - $\quad$ Polyphenolic extracts & & & $0.15-0.3 \mathrm{mg} / \mathrm{L}$ & [83] \\
\hline & Resveratrol & & & $0.1-0.2 \mathrm{mg} / \mathrm{mL}$ & [84] \\
\hline & Diallyl sulphide & & & $0.04 \mathrm{mg} / \mathrm{mL}$ & [85] \\
\hline $\begin{array}{l}\text { Antimicrobial } \\
\text { peptides (AMPs) }\end{array}$ & Puroindoline A (PinA) & $\begin{array}{l}\text { - } \text { quorum } \\
\text { sensing- } \\
\text { mediated } \\
\text { inhibition of } \\
\text { EPS production. }\end{array}$ & C. jejuni 81-176 & $512 \mu \mathrm{g} / \mathrm{mL}$ & {$[56,86,87]$} \\
\hline \multicolumn{6}{|c|}{ Microorganism-derived compounds } \\
\hline Algae extracts & Delisea pulchra extract & $\begin{array}{l}\text { - } \quad \text { inhibit the } \\
\text { activity of AI-2 } \\
\text { molecules }\end{array}$ & C. jejuni NCTC 11168 & $230 \mu \mathrm{g} / \mathrm{mL}$ & [88] \\
\hline $\begin{array}{l}\text { D-amino acids } \\
\text { (DAs) }\end{array}$ & $\begin{array}{ll}- & \text { D-Methionine } \\
- & \text { D-Tryptophan } \\
- & \text { D-Serine } \\
- & \text { D-Alanine }\end{array}$ & 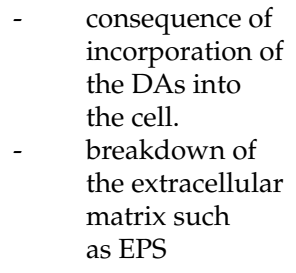 & C. jejuni NCTC 11168 & $5-100 \mathrm{mM}$ & [47] \\
\hline $\begin{array}{l}\text { Probiotic- } \\
\text { derived } \\
\text { factors }\end{array}$ & $\begin{array}{ll}- & \text { Bacteriocin } \\
- & \text { Reuterin }\end{array}$ & $\begin{array}{ll}\text { - } & \text { interfering with } \\
\text { DNA synthesis } \\
\text { - } \quad \text { interfering with } \\
\text { the membrane } \\
\text { integrity of } \\
\text { bacterial cells }\end{array}$ & $\begin{array}{l}\text { C. jejuni } \\
\text { C. coli }\end{array}$ & $\begin{array}{c}0.025-32 \mu \mathrm{g} / \mathrm{mL} \\
1.5-5.8 \mu \mathrm{M}\end{array}$ & $\begin{array}{l}{[89]} \\
{[90]}\end{array}$ \\
\hline $\begin{array}{l}\text { Glycolipid } \\
\text { Biosurfactant }\end{array}$ & Sophorolipid & $\begin{array}{l}\text { - lysis of the cell } \\
\text { membrane }\end{array}$ & $\begin{array}{l}\text { C. jejuni subsp. jejuni } \\
33560\end{array}$ & $0.003 \%$ & [88] \\
\hline
\end{tabular}

${ }^{*}$ Minimum inhibitory concentrations (MIC) as determined by the broth microdilution method described in individual references.

\subsection{Plant-Derived Compounds}

Essential oils (EOs) derived from plants are promising antimicrobial compounds, with over $\sim 300$ commercially available EOs. Many EOs (e.g., cinnamon oil, clove oil and lavender essential oil) exhibit antibacterial, antibiofilm and antifungal properties which have a wide range of applications in the food and dietary supplement industry [91-95]. EOs are also reported to prevent biofilm formation on abiotic surfaces, which has encouraged the development of alternative disinfection strategies, targeting contaminated surfaces and 
equipment used in food processing [96-99]. Moreover, EOs have been added to animal feed and water as taste enhancers for livestock nutrients and as growth promoters, particularly in poultry and porcine farming $[94,100,101]$. Here, we describe some compounds that exhibit promising antimicrobial and antibiofilm activities against campylobacters.

Cinnamon oil (Cinnamomum cassia) and clove oil (Eugenia caryophyllus) are reported to have bioactive compounds such as cinnamaldehyde (CA), eugenol (EG) and carvacrol (CR) [92]. These compounds act as antimicrobial and antibiofilm agents against many pathogens including P. aeruginosa, Salmonella Typhimurium, Streptococcus mutans and Listeria monocytogenes [102-105]. CA, EG and CR also exhibit an ability to significantly decrease Campylobacter spp. biofilms and remove the biofilms from stainless steel and polystyrene surfaces $[71-74,106]$. Several studies revealed the effectiveness of CR to reduce C. jejuni in vitro and in vivo [107-112]. For instance, Wagle et al. [106] found that the minimum inhibitory concentration (MIC) of CR (at $0.002 \%$ ) was able to reduce the C. jejuni adhesion to primary chicken enterocytes (in an in vitro model of chicken intestinal physiology) up to $1.5 \log \mathrm{cfu} / \mathrm{mL}$ as compared with control. Interestingly, CR downregulated the expression of $C$. jejuni colonisation factors, critical for persistence in the chicken gut, such as chemotaxis (aspartate chemoreceptor, $C c a A$ ), interactions with host cells (asp $A$ ) and anaerobic respiration (NapB). Similar to that, šimunović et al. [112] demonstrated that CR (MIC $0.0032 \%$ ), as a pure compound or in synergistic combinations with thymoquinone, and rosmarinic acid, not only has antimicrobial activity against $C$. jejuni but also can increase the antibiotic susceptibility of $C$. jejuni by inhibiting the efflux pump activity. Unfortunately, further attempts to determine antibacterial properties of $C R$ against $C$. jejuni using the broiler chicken model were inconsistent. Arsi et al. [113] reported that CR supplemented feed at $0.5-1 \%$ could significantly reduce Campylobacter counts in broiler chicks, either alone or in combination with thymol. However, their results could not be replicated in other trials, reportedly due to absorption of those compounds before they reach their target, the small intestine and caeca of chickens, or effects of other enteric microflora [109]. To improve the in vivo outcomes, Allaoua et al. [109] used a CR-based product, solid galenic $\mathrm{CR}$ formulation, designed to delay the $\mathrm{CR}$ release to allow it to reach the caeca of broiler chickens in order to control C. jejuni. This new formulation was aimed to preserve the antibacterial efficacy of $C R$ against $C$. jejuni by allowing $C R$ to reach the caeca and large intestine at an effective concentration (at MIC $0.02 \mathrm{mg} / \mathrm{mL}$ ), which significantly decreased the C. jejuni caecal load (by $1.5 \mathrm{log}$ ). Kelly et al. [108] also reported that CR was able to reduce Campylobacter cell adhesion and invasion of chicken intestinal primary cells and also biofilm formation in vitro. They also showed that $\mathrm{CR}$ was able to delay colonisation of chicken broilers by inducing changes in gut microflora. Campylobacter spp. was only detected at 35 days of life in the treatment groups compared with the control group where the colonisation occurred at 21 days. Reducing the number of campylobacteria in the chicken intestine is a goal of most studies as quantitative risk assessment models indicate that a reduction of $C$. jejuni numbers on a broiler carcass by 100 -fold (or $2 \log$ units) could result in a significant reduction, by 30 times, in the incidence of campylobacteriosis [114]. Even a relatively small reduction in C. jejuni numbers in the chicken cecum by $1 \log _{10} \mathrm{CFU}$ can reduce the public health risk by more than $50 \%$ [8]. In addition, CR had a significant effect on E. coli numbers in the cecum of the chickens in treatment groups. Similarly, Szott et al. [111] found that CR additive could reduce $C$. jejuni counts in vivo by $1.17 \mathrm{log}$ (up to 28 days of age); however, CR did not successfully reduce Campylobacter caecal colonisation in 33-day-old broilers. Interestingly, addition of CR to the diet decreased feed intake increased feed conversion rates and body weight at all levels of supplementation [115]. Similarly, combining basic diet with cinnamon oil ( $0.3 \mathrm{~g}$ of cinnamon oil per $\mathrm{kg})$ could enhance daily weight gain of broiler chickens by $5.1 \%$ [116]. One more potential advantage of using CR is its effect on probiotic bacteria where the additional proliferation of probiotic bacteria such as Lactobacillus and Bifidobacteria spp. has been proposed to be a potential mechanism of inhibiting avian colonisation by disease-causing organisms such as Campylobacter spp. [91,117]. The important benefit, all studies agree, is that CR is safe to 
use as a dietary supplement in the chicken diet and could improve poultry health, feed efficiency, and delay Campylobacter colonisation in chickens.

Lavender essential oil (LEO) has antiviral activity against Herpes simplex virus type 1 [118]; antibacterial activity against piperacillin-resistant $E$. coli J53 R1, chloramphenicol-resistant L. monocytogenes L120, S. aureus MRSA and P. aeruginosa [119-122]; and antifungal activity against Aspergillus niger and Aspergillus tubingensis [123]. LEOs also show an antibiofilm activity against $C$. jejuni with MIC ranged from $0.2 \mathrm{mg} / \mathrm{mL}$ to $1 \mathrm{mg} / \mathrm{mL}$ [124]. LEOs were reported to downregulate a range of genes (i.e., Cj0719c, kpsS, lgt, maf4, waaC and Cj1467), involved in the initial attachment of Campylobacter spp. cells to abiotic and biotic surfaces. Adaszynska et al. [122] have evaluated the effect of LEO on chicken production by adding LEO to drinking water given to broiler chickens. The results of the experiments not only showed a significant inhibition of microbial growth, but also a significant increase in the body weight of the chickens in the groups receiving LEO as compared with the control group. Similarly, juniper essential oil (JEO) had shown potent anti-adherent effects against C. jejuni $[67,74,76,125]$, where flavonoid-rich fractions from juniper, at $1 \mathrm{mg} / \mathrm{mL}$, were able to inhibit attachment of C. jejuni cells to polystyrene by up to $70-99 \%$, and reduced the invasion of INT407 cells by $76 \%$. $\alpha$ - and $\beta$-pinene are another example of essential oil components from Alpinia katsumadai seeds that can have antimicrobial, antimalarial, and antioxidant effects [77,126-128]. The antimicrobial activities of (-)- $\alpha$-pinene were reported against Campylobacter spp. in vitro; however, (-)- $\alpha$-pinene alone showed a low efficacy with $\mathrm{MIC}_{50}>500 \mathrm{mg} / \mathrm{L}$ required to inhibit $50 \%$ of the strains, but when (-)- $\alpha$-pinene was combined with antibiotics ciprofloxacin and erythromycin, strong potentiating effects against different Campylobacter strains were observed. The concentrations of antibiotics could be decreased from $1 \mathrm{mg} / \mathrm{mL}$ to $0.002 \mathrm{mg} / \mathrm{mL}$ for ciprofloxacin, and from $512 \mathrm{mg} / \mathrm{mL}$ to $<1 \mathrm{mg} / \mathrm{mL}$ for erythromycin [129]. Possible applications of such natural compounds could be in food packaging to maintain food quality and reduce cross-contamination, or as feed additives to increase weight gain of chickens and by reducing the costs associated with antimicrobial feed additives.

Citrus Extracts (CE) have been widely used in many applications in pharmaceuticals and food industry due to their properties as antimicrobial, insecticidal and antifungal agents $[130,131]$. CEs showed the ability to reduce the biofilm formation of pathogenic bacteria, for example, Staphylococcus spp., Pseudomonas spp. and E. coli due to their antimicrobial activity [132-134]. Castillo et al. [79] found that treatment with CE (such as citron, bitter orange, lime, lemon and tangerine) elicits a strong inhibitory effect, up to $75 \%$, on C. jejuni biofilm formation. This compound could also decrease the activity of C. jejuni quorum-sensing signalling (AI-2 QS) [79]. As another example, grapefruit seed extract (GSE), widely used in the food industry as a safe and effective preservative [135], has an antibiofilm and antibacterial activity against methicillin-resistant S. aureus (MRSA), vancomycin-resistant S. aureus (VRSA) and E. coli [135-137]. GSE can also inhibit C. jejuni growth and its adhesion to abiotic and biotic surfaces (at a minimum bactericidal concentration (MBC) of $60 \mathrm{mg} / \mathrm{L}$ ) [78,138]. GSE consists of many phenolic compounds such as anthocyanins, catechins, flavonols, phenolic acids and proanthocyanidins. Among them, phenolic acids, catechins and proanthocyanidins have a strong inhibitory effects on C. jejuni growth [78]. Phenolic acids and catechins could also inhibit the growth of Campylobacter strains, with MIC range between 10 and $100 \mathrm{mg} / \mathrm{L}$, which could be useful for the control of Campylobacter transmission through the foods chain. In addition, dietary supplements that contain grape seed as a source of phenolic compounds, have shown to promote higher body weight gain in broilers [139]. Further advantage of GSE phenolic compounds is offered by their effectiveness against Gram-positive bacteria via inhibition of the cell wall biosynthesis, and Gram-negative bacteria via break-down of the outer membranes $[135,138,140,141]$. Currently, GSE is used commercially as a dietary supplement and, therefore, has the potential to be safely used at different points of the food chain to reduce the transmission of campylobacteriosis. 
Ethanol solution extract (EREE): Plant-based ethanol extracts have been previously used to control food-borne pathogens and multidrug-resistant bacteria [142-144]. For example, Euodia ruticarpa ethanol solution extract (EREE) contains bioactive components, such as evodiamine, rutaecarpine and evocarpine which have shown promising antimicrobial activities against $S$. aureus MRSA, mycobacterial strains, and $C$. jejuni which are able to inhibit cell adhesion and biofilm formation [80,144-146]. EREE exhibited antibiofilm and anti-AI-2 QS properties against C. jejuni at MIC from 64 to $1024 \mu \mathrm{g} / \mathrm{mL}$ [80], indicating that quinolinone alkaloids have potential to reduce the cell-surface bacterial attachment by interfering with the QS system.

Polyphenolic extracts: Similar to other natural products, polyphenols extracted from plants have been reported to have antimicrobial and antibiofilm activities [68,147-151]. For example, polyphenol-rich cranberry and other berry extracts have strong antibiofilm effect on dual-species Streptococcus mutans-Candida albicans biofilms and sole Streptococcus mutans biofilms [152,153]. Similarly, polyphenolic components found in spray-dried olive mill wastewater (OMWW-SD) inhibit Campylobacter spp. biofilm formation and promote biofilm dispersion [84]. Those polyphenols, mainly secoiridoid and hydroxycinnamic acid derivatives with MIC ranged between 0.15 to $0.3 \mathrm{mg} / \mathrm{mL}$, were able to inhibit biofilm formation by Campylobacter strains between 50-92\%, depending on concentration. In addition, gallic acid and taxifolin significantly affected $\mathrm{Cme} A B C$ multidrug efflux pump expression resulting in increased bacterial susceptibility to ciprofloxacin and erythromycin in C. jejuni isolates, where $8 \mu \mathrm{g} / \mathrm{mL}$ of the phenolic compounds combined with ciprofloxacin and erythromycin reduced the MIC of those antibiotics 4-32-fold [154]. Green tea is also rich in naturally occurring polyphenolics such as epicatechin (EC), gallocatechin (GC), gallocatechin gallate (GCG), epigallocatechin (EGC), epicatechin gallate (ECG) and epigallocatechin gallate (EGCG). These compounds have potent antioxidant activity and antimicrobial properties [155-157]. The extracted EGCG exhibits antimicrobial activity and anti-AI-2 QS activity against E. coli [134], and inhibited C. jejuni biofilm formation by $75 \%$ at concentrations of 31 to $125 \mu \mathrm{g} / \mathrm{mL}$ [83]. This study suggested that green tea extract could be used to restrict growth of $C$. jejuni by interfering with biofilm formation and QS activity, as well as facilitate the performance and health of broilers $[158,159]$.

Another compound to be considered is a commonly used dietary supplement, resveratrol (3,5,4'-trihydroxystilbene). It is produced by several plants and can be found in skin of blueberries and grapes. Resveratrol has been reported to inhibit biofilm formation and to disperse established biofilms and also has an inhibitory activity against a range of bacterial pathogens [85,160]. The antibiofilm activity of resveratrol, with up to $94 \%$ C. jejuni, and C. coli biofilm inhibition at MIC of $0.1-0.2 \mathrm{mg} / \mathrm{mL}$, suggests a potential use of this compound as antibiofilm agent in poultry meat processing, food preparation and packaging. Together, these findings suggest that the use of polyphenolic extracts could be used to limit campylobacterial growth and biofilm formation in animal food products processing, particularly poultry, and consequently enhance food safety and limit the use of chemical additives or preservatives.

Organosulfur compounds: Organosulfur compounds derived from garlic (Allium sativum) such as allicin, ajoenes and diallyl sulphide, have shown antimicrobial activity against a vast range of pathogens [161-163]. These compounds also have been tested as antimicrobial wash for poultry meat to reduce the number of $C$. jejuni cells $[81,82,163]$. Organosulfur compounds could be a safer and cheaper alternative to commonly used antimicrobials, such as peracetic acid (PAA), in an effort to reduce contamination during pre- and post-chill carcass and broiler parts treatments [164]. Remarkably, diallyl sulphide was not only able to destroy the EPS structure of the $C$. jejuni biofilm but also eliminated planktonic and sessile cells [82]. Diallyl sulphide, and other bioactive organosulfur compounds, have potential for reducing bacterial cell adherence, inhibiting production of AI-2 QS molecule, and enhancing disruption of cell surface structure of this pathogen. Wagle et al. [81] showed that the application of organosulfur compounds such as diallyl sulphide as antimicrobial wash in postharvest poultry could significantly reduce $C$. jejuni numbers on poultry meat. 
Antimicrobial peptides (AMPs) are naturally occurring peptides produced by many multicellular organisms as a first-line immune defence. Many AMPs exhibit broadspectrum antimicrobial activity which can target both Gram-positive and -negative bacteria [165-168]. Wheat proteins puroindolines, present in Triticum aestivum endosperm, are found in two major isoforms, puroindoline A (PinA) and puroindoline B (PinB). Both have antimicrobial properties due to presence of tryptophan-rich domains (TRDs) $[168,169]$. TRD-rich peptides have a high affinity for the negatively charged lipids in the bacterial membranes and have antimicrobial effect against many pathogens such as E. coli, S. aureus, L. monocytogenes, and Aspergillus flavus [169,170]. The mode of action of PinA is via membrane destabilization, while PinB targets DNA by inhibiting DNA replication [171,172]. In case of Campylobacter strains, PinA has been shown to affect both, bacterial growth and biofilm formation [168]. PinA could inhibit C. jejuni 81-176 biofilm formation at the concertation of $512 \mu \mathrm{g} / \mathrm{mL}$ and growth at $16-32 \mu \mathrm{g} / \mathrm{mL}$. Interestingly, using PinA in combination with erythromycin and ciprofloxacin, antibiotics commonly used to treat $C$. jejuni infections, was more effective in reducing $C$. jejuni growth than using any antibiotic alone, indicating a potential use for PinA as an enhancer of antibiotic efficacy.

\subsection{Microorganism-Derived Compounds}

Algae extracts: Many antibacterial compounds have been identified in marine organisms including algal classes such as the Bacillariophyceae (diatoms), Chlorophyceae, Chrysophyceae, Rhodophyceae and Phaeophyceae [173-175]. Algal extracts containing bioactive compounds such as fatty acids and furanone [176-178], have been widely used for pharmaceutical and industrial applications. For example, the long-chain fatty acids in the green microalga Planktochlorella nurekis has been reported to have antibacterial activity against many pathogens, including C. jejuni, at concentrations between $0.75-6 \mathrm{mg} / \mathrm{mL}$ [179]. Brominated furanone is a naturally occurring polyphenolic compound with antimicrobial properties that can be extracted from Delisea pulchra algae. This compound can exert antibiofilm activity against $C$. jejuni, by interfering with AI-2 QS, at MBC $230 \mu \mathrm{g} / \mathrm{mL}[83,175]$. Such algae have been previously used as safe food additives for poultry [180], as their rich nutrients enhance growth performance and product quality with a possible additional benefit of reducing human food-borne illness.

D-amino acids (DAs): While most proteins are composed of L-amino acids, D-amino acids, DAs, can be found in cell walls of many bacteria. Interestingly, addition of external DAs had been shown to have antibiofilm properties in a variety of species such as B. subtilis, S. aureus and P. aeruginosa [181-184]. Moreover, the use of DAs in various combinations enhanced the activity of antimicrobial agents such as colistin, ciprofloxacin and rifampin, frequently used to treat $P$. aeruginosa and S. aureus [185]. For C. jejuni, a mixture of D-serine, D-Tryptophane and D-methionine at concentration $5 \mathrm{mM}$ was found to be able to inhibit the biofilm formation or disrupt mature biofilm. Moreover, DAs disrupted the ability of C. jejuni to form biofilm (up to 70\%) by incorporating into peptidoglycan and inducing the disassembly of matrix-associated amyloid fibrils, or by a breakdown of EPS that surrounds the biofilm. DAs were also able to enhance the efficacy of D-Cycloserine (DCS) against C. jejuni by up to $32 \%$ [47]. DAs appear to be promising antibiofilm compounds and should be further investigated.

Probiotic-derived factors: Several studies have reported the ability of probiotic organisms, such as Lactobacillus spp., to secrete probiotic factors (e.g., bacteriocin and reuterin) which have shown antimicrobial activities against various enteric pathogens such as E. coli, and Vibrio cholerae [186]. In addition, these factors have also been reported to have a beneficial effects on the intestinal epithelium through an improvement of intestinal barrier function leading to reduced permeability to pathogens [187]. For example, bacteriocins of probiotic Lactobacilli, are naturally produced as secondary metabolites, display antimicrobial, antiviral and antifungal activities. Bacteriocins have been recognized as non-toxic alterative antibiotics against gastrointestinal infections [188,189]. Bacteriocins had also shown antibiofilm activity against P. aeruginosa PAO1 and B. subtilis BM19. Bacteriocins act 
by interfering with the membrane integrity of bacterial cells leading to cell death [186]. Several bacteriocins have been isolated and characterized from commensal bacteria in chicken intestines, such as Enterococcus faeciu (E50-52) and Lactobacillus salivarius (e.g., OR-7) and can inhibit proliferation of Campylobacter spp. [90,188,190]. For instance, feeding bacteriocins E50-52, MIC ranged from 0.025 to $32 \mu \mathrm{g} / \mathrm{mL}$, to broiler chickens reduced C. jejuni cell numbers by more than $99 \%$ in the caeca [90].

Another example of probiotic-produced antimicrobial compound is reuterin, which is produced as a byproduct of anaerobic fermentation of glycerol by Lactobacillus reuteri [89]. The main active antimicrobial fraction of reuterin is acrolein. Acrolein is proposed to interfere with DNA synthesis by inhibiting the activity of bacterial ribonucleotide reductase $[89,191]$. Several studies found that reuterin and reuterin-related compounds exhibit antimicrobial and antibiofilm activities against wide range of Gram-positive and -negative bacteria including B. subtilis, Clostridium difficile, E. coli, Fusobacterium nucleatum, Listeria spp. and P. aeruginosa $[67,89,191-194]$. Reuterin also suppressed the growth of Campylobacter strains with MIC range between 1.5 to $5.8 \mu \mathrm{M}$. Use of bacteriocins and reuterin compounds appears to be a promising avenue to explore for control of campylobacters in poultry and poultry products by adding these natural products as feed additives in poultry diet [195].

Glycolipid Biosurfactant: Glycolipids, with potential anticancer and antimicrobial activities, already have a wide range of therapeutic applications including in pharmaceutical, food, and petroleum industries [196]. Sophorolipid is one of glycolipid molecules produced by the yeast Starmerella bombicola with antimicrobial and antibiofilm activities against foodborne pathogens such as E. coli, Salmonella spp. and C. jejuni [88,197,198]. Sophorolipid acts by inducing lysis of the cell membrane of pathogens, resulting in the release of cytoplasm contents [88,199]. Sophorolipid is a promising natural antimicrobial compound composed of biodegradable carbohydrate-based molecules with mild cytotoxicity, which makes them very attractive for the poultry industry $[88,200]$. One suggested application of sophorolipid is in the preservation and decontamination of meat products [88,200,201]. Silveira et al. [88], found that the combination of sophorolipid and lactic acid to treat Campylobacters cells resulted in an additive interaction and reduced the concentration required to treat campylobacters by $50 \%$. Although lactic acid is commonly used in the poultry industry $[202,203]$ and is approved by Food and Drug Administration (FDA), the treatment may negatively affect product quality by inducing changes in colour and flavour [204]. The combination of sophorolipid and lactic acid at reduced concentrations could provide an alternative treatment which would minimise the microbial contamination and preserve the aesthetic appeal and flavour of the foodstuffs.

\section{Concluding Remarks}

Solving the problem of gastroenteritis due to C. jejuni is an important challenge not only for improving the microbiological safety of food worldwide, but for reducing the enormous economic burden of hospitalisation, treatment, and loss of productivity caused by infection with these organisms. We postulate that the ability of $C$. jejuni to integrate into mixed-species biofilms is central for the efficient intestinal colonisation of the avian host and its transmission to human host. As is the case with other enteric pathogens, abolishing the ability to integrate into such a biofilm, will effectively limit transmission of this pathogen and reduce the incidence of disease in the human population. Therefore, innovative approaches of targeting zoonotic pathogens at the point of transmission from animal hosts to humans have an enormous potential to reduce or eliminate human infections, limiting the need for hospitalisation, treatment and vaccination.

Using natural products to disrupt the chain of pathogen transmission by using these as animal food additives, packaging disinfectants and bacterial growth inhibitors, offers great potential for an antibiotic-free path for foodstuffs from farm to fork. Furthermore, the application of natural compounds to enhance the efficacy of antibiotics, currently used to treat food-borne infections, offers additional advantages in our fight against the rise of antibiotic resistance. Further investigation of practical application of naturally occurring antibiofilm 
and antimicrobial compounds is required in order to progress the development of future preventative and therapeutic strategies to control the transmission of food borne diseases.

Author Contributions: Conceptualization, B.A.E. and V.K.; validation, B.A.E. and V.K.; writingoriginal draft preparation, B.A.E. and V.K.; writing-review and editing, B.E and V.K; supervision, V.K; project administration, V.K. All authors have read and agreed to the published version of the manuscript.

Funding: This research received no external funding.

Institutional Review Board Statement: Not applicable.

Informed Consent Statement: Not applicable.

Data Availability Statement: Not applicable.

Conflicts of Interest: The authors declare no conflict of interest.

\section{References}

1. Phillips, P.L.; Schultz, G.S. Molecular mechanisms of biofilm infection: Biofilm virulence factors. Adv. Wound Care 2012, 1, 109-114. [CrossRef]

2. Epps, S.V.; Harvey, R.B.; Hume, M.E.; Phillips, T.D.; Anderson, R.C.; Nisbet, D.J. Foodborne Campylobacter: Infections, metabolism, pathogenesis and reservoirs. Int. J. Environ. Res. Public Health 2013, 10, 6292-6304. [CrossRef]

3. Culotti, A. Environmental Biofilms: A Reservoir for Pathogens in Water Distribution Systems. Ph.D. Thesis, Northwestern University, Evanston, IL, USA, 2014.

4. Techaruvichit, P.; Takahashi, H.; Kuda, T.; Miya, S.; Keeratipibul, S.; Kimura, B. Adaptation of Campylobacter jejuni to biocides used in the food industry affects biofilm structure, adhesion strength, and cross-resistance to clinical antimicrobial compounds. Biofouling 2016, 32, 827-839. [CrossRef]

5. Vlamakis, H. The World of Biofilms; Taylor \& Francis: Abingdon, UK, 2011.

6. Ica, T.; Caner, V.; Istanbullu, O.; Nguyen, H.D.; Ahmed, B.; Call, D.R.; Beyenal, H. Characterization of mono- and mixed-culture Campylobacter jejuni biofilms. Appl. Environ. Microbiol. 2012, 78, 1033-1038. [CrossRef]

7. Buzby, J.C.; Allos, B.M.; Roberts, T. The economic burden of Campylobacter-associated Guillain-Barré syndrome. J. Infect. Dis. 1997, 176, S192-S197. [CrossRef]

8. World Health Organization. The Global View of Campylobacteriosis: Report of an Expert Consultation, Utrecht, Netherlands, 9-11 July 2012; WHO: Geneva, Switzerland, 2013.

9. Van den Berg, B.; Walgaard, C.; Drenthen, J.; Fokke, C.; Jacobs, B.C.; van Doorn, P.A. Guillain-Barre syndrome: Pathogenesis, diagnosis, treatment and prognosis. Nat. Rev. Neurol. 2014, 10, 469-482. [CrossRef] [PubMed]

10. Igwaran, A.; Okoh, A.I. Human campylobacteriosis: A public health concern of global importance. Heliyon 2019, 5, e02814. [CrossRef]

11. Man, S.M. The clinical importance of emerging Campylobacter species. Nat. Rev. Gastroenterol. Hepatol. 2011, 8, 669-685. [CrossRef] [PubMed]

12. Whiley, H.; van den Akker, B.; Giglio, S.; Bentham, R. The role of environmental reservoirs in human campylobacteriosis. Int. J. Environ. Res. Public Health 2013, 10, 5886-5907. [CrossRef] [PubMed]

13. Ellis-Iversen, J.; Ridley, A.; Morris, V.; Sowa, A.; Harris, J.; Atterbury, R.; Sparks, N.; Allen, V. Persistent environmental reservoirs on farms as risk factors for Campylobacter in commercial poultry. Epidemiol. Infect. 2012, 140, 916-924. [CrossRef]

14. Carrascosa, C.; Raheem, D.; Ramos, F.; Saraiva, A.; Raposo, A. Microbial biofilms in the food industry-A comprehensive review. Int. J. Environ. Res. Public Health 2021, 18, 2014. [CrossRef] [PubMed]

15. Bronowski, C.; James, C.E.; Winstanley, C. Role of environmental survival in transmission of Campylobacter jejuni. FEMS Microbiol. Lett. 2014, 356, 8-19. [CrossRef] [PubMed]

16. Backert, S.; Tegtmeyer, N.; Cróinín, T.Ó.; Boehm, M.; Heimesaat, M.M. Human campylobacteriosis. In Campylobacter; Elsevier: Amsterdam, The Netherlands, 2017; pp. 1-25.

17. Peyrat, M.; Soumet, C.; Maris, P.; Sanders, P. Recovery of Campylobacter jejuni from surfaces of poultry slaughterhouses after cleaning and disinfection procedures: Analysis of a potential source of carcass contamination. Int. J. Food Microbiol. 2008, 124, 188-194. [CrossRef]

18. González, M.; Hänninen, M.L. Effect of temperature and antimicrobial resistance on survival of Campylobacter jejuni in well water: Application of the Weibull model. J. Appl. Microbiol. 2012, 113, 284-293. [CrossRef] [PubMed]

19. Magajna, B.A.; Schraft, H. Campylobacter jejuni biofilm cells become viable but non-culturable (VBNC) in low nutrient conditions at $4 \mathrm{C}$ more quickly than their planktonic counterparts. Food Control 2015, 50, 45-50. [CrossRef]

20. Lv, R.; Wang, K.; Feng, J.; Heeney, D.D.; Liu, D.; Lu, X. Detection and quantification of viable but non-culturable Campylobacter jejuni. Front. Microbiol. 2020, 10, 2920. [CrossRef]

21. Pitkänen, T. Review of Campylobacter spp. in drinking and environmental waters. J. Microbiol. Methods 2013, 95, 39-47. [CrossRef] 
22. Stetsenko, V.; Efimochkina, N.; Pichugina, T. Growth and persistence of Campylobacter jejuni in foodstuffs. Bull. Exp. Biol. Med. 2019, 166, 759-765. [CrossRef] [PubMed]

23. Kim, S.-H.; Chelliah, R.; Ramakrishnan, S.R.; Perumal, A.S.; Bang, W.-S.; Rubab, M.; Daliri, E.B.-M.; Barathikannan, K.; Elahi, F.; Park, E. Review on stress tolerance in Campylobacter jejuni. Front. Cell. Infect. Microbiol. 2020, 10, 596570. [CrossRef] [PubMed]

24. Zhong, X.; Wu, Q.; Zhang, J.; Ma, Z.; Wang, J.; Nie, X.; Ding, Y.; Xue, L.; Chen, M.; Wu, S. Campylobacter jejuni biofilm formation under aerobic conditions and inhibition by ZnO nanoparticles. Front. Microbiol. 2020, 11, 207. [CrossRef] [PubMed]

25. Teh, A.H.; Lee, S.M.; Dykes, G.A. Does Campylobacter jejuni form biofilms in food-related environments? Appl. Environ. Microbiol. 2014, 80, 5154-5160. [CrossRef] [PubMed]

26. Mah, T.-F. Biofilm-specific antibiotic resistance. Future Microbiol. 2012, 7, 1061-1072. [CrossRef] [PubMed]

27. Bridier, A.; Sanchez-Vizuete, P.; Guilbaud, M.; Piard, J.-C.; Naïtali, M.; Briandet, R. Biofilm-associated persistence of food-borne pathogens. Food Microbiol. 2015, 45, 167-178. [CrossRef] [PubMed]

28. Joshua, G.P.; Guthrie-Irons, C.; Karlyshev, A.; Wren, B. Biofilm formation in Campylobacter jejuni. Microbiology 2006, 152, 387-396. [CrossRef]

29. Brown, H.L.; Reuter, M.; Salt, L.J.; Cross, K.L.; Betts, R.P.; van Vliet, A.H. Chicken juice enhances surface attachment and biofilm formation of Campylobacter jejuni. Appl. Environ. Microbiol. 2014, 80, 7053-7060. [CrossRef] [PubMed]

30. Reuter, M.; Mallett, A.; Pearson, B.M.; van Vliet, A.H. Biofilm formation by Campylobacter jejuni is increased under aerobic conditions. Appl. Environ. Microbiol. 2010, 76, 2122-2128. [CrossRef]

31. Iovine, N.M. Resistance mechanisms in Campylobacter jejuni. Virulence 2013, 4, 230-240. [CrossRef]

32. Smith, J.L.; Fratamico, P.M. Fluoroquinolone resistance in Campylobacter. J. Food Prot. 2010, 73, 1141-1152. [CrossRef]

33. Golz, J.C.; Stingl, K. Natural competence and horizontal gene transfer in Campylobacter. In Fighting Campylobacter Infections: Towards a One Health Approach; Springer Nature: Basingstoke, UK, 2021; pp. 265-292.

34. Vegge, C.S.; Brøndsted, L.; Ligowska-Marzęta, M.; Ingmer, H. Natural transformation of Campylobacter jejuni occurs beyond limits of growth. PLoS ONE 2012, 7, e45467. [CrossRef]

35. Han, J. Molecular Mechanisms Involved in the Emergence and Fitness of Fluoroquinolone-Resistant Campylobacter jejuni; Iowa State University: Ames, IA, USA, 2009.

36. World Health Organization. WHO Publishes List of Bacteria for Which New Antibiotics Are Urgently Needed; WHO: Geneva, Switzerland, 2017.

37. Silva, J.; Leite, D.; Fernandes, M.; Mena, C.; Gibbs, P.A.; Teixeira, P. Campylobacter spp. as a foodborne pathogen: A review. Front. Microbiol. 2011, 2, 200. [CrossRef] [PubMed]

38. Whitehouse, C.A.; Zhao, S.; Tate, H. Antimicrobial resistance in Campylobacter species: Mechanisms and genomic epidemiology. Adv. Appl. Microbiol. 2018, 103, 1-47. [PubMed]

39. Li, J.; Feng, J.; Ma, L.; de la Fuente Núñez, C.; Gölz, G.; Lu, X. Effects of meat juice on biofilm formation of Campylobacter and Salmonella. Int. J. Food Microbiol. 2017, 253, 20-28. [CrossRef]

40. Scheik, L.K.; Volcan Maia, D.S.; Würfel, S.D.F.R.; Ramires, T.; Kleinubing, N.R.; Haubert, L.; Lopes, G.V.; da Silva, W.P. Biofilmforming ability of poultry Campylobacter jejuni strains in the presence and absence of Pseudomonas aeruginosa. Can. J. Microbiol. 2021, 67, 301-309. [CrossRef]

41. Brown, H.L.; Reuter, M.; Hanman, K.; Betts, R.P.; van Vliet, A.H. Prevention of Biofilm Formation and Removal of Existing Biofilms by Extracellular DNases of Campylobacter jejuni. PLoS ONE 2015, 10, e0121680. [CrossRef]

42. Svensson, S.L.; Pryjma, M.; Gaynor, E.C. Flagella-mediated adhesion and extracellular DNA release contribute to biofilm formation and stress tolerance of Campylobacter jejuni. PLoS ONE 2014, 9, e106063. [CrossRef] [PubMed]

43. Turonova, H.; Briandet, R.; Rodrigues, R.; Hernould, M.; Hayek, N.; Stintzi, A.; Pazlarova, J.; Tresse, O. Biofilm spatial organization by the emerging pathogen Campylobacter jejuni: Comparison between NCTC 11168 and 81-176 strains under microaerobic and oxygen-enriched conditions. Front. Microbiol. 2015, 6, 709. [CrossRef] [PubMed]

44. Gaasbeek, E.J.; Wagenaar, J.A.; Guilhabert, M.R.; Wösten, M.M.; van Putten, J.P.; van der Graaf-van Bloois, L.; Parker, C.T.; van der Wal, F.J. A DNase encoded by integrated element CJIE1 inhibits natural transformation of Campylobacter jejuni. J. Bacteriol. 2009, 191, 2296-2306. [CrossRef]

45. Van Houdt, R.; Michiels, C.W. Role of bacterial cell surface structures in Escherichia coli biofilm formation. Res. Microbiol. 2005, 156, 626-633. [CrossRef] [PubMed]

46. Turonova, H.; Neu, T.R.; Ulbrich, P.; Pazlarova, J.; Tresse, O. The biofilm matrix of Campylobacter jejuni determined by fluorescence lectin-binding analysis. Biofouling 2016, 32, 597-608. [CrossRef]

47. Elgamoudi, B.A.; Taha, T.; Korolik, V. Inhibition of Campylobacter jejuni biofilm formation by D-amino acids. Antibiotics 2020, 9 , 836. [CrossRef]

48. Palmer, J.; Flint, S.; Brooks, J. Bacterial cell attachment, the beginning of a biofilm. J. Ind. Microbiol. Biotechnol. 2007, 34, 577-588. [CrossRef] [PubMed]

49. Flemming, H.-C.; Wingender, J. The biofilm matrix. Nat. Rev. Micro. 2010, 8, 623-633. [CrossRef] [PubMed]

50. Melo, R.T.; Mendonça, E.P.; Monteiro, G.P.; Siqueira, M.C.; Pereira, C.B.; Peres, P.A.; Fernandez, H.; Rossi, D.A. Intrinsic and extrinsic aspects on Campylobacter jejuni biofilms. Front. Microbiol. 2017, 8, 1332. [CrossRef] [PubMed]

51. Kostakioti, M.; Hadjifrangiskou, M.; Hultgren, S.J. Bacterial biofilms: Development, dispersal, and therapeutic strategies in the dawn of the postantibiotic Era. Cold Spring Harb. Perspect. Med. 2013, 3, a010306. [CrossRef] [PubMed] 
52. Das, T.; Manefield, M. Pyocyanin promotes extracellular DNA release in Pseudomonas aeruginosa. PLoS ONE 2012, 7, e46718. [CrossRef]

53. Kaplan, J.B. Biofilm dispersal: Mechanisms, clinical implications, and potential therapeutic uses. J. Dent. Res. 2010, 89, 205-218. [CrossRef]

54. Ma, L.; Conover, M.; Lu, H.; Parsek, M.R.; Bayles, K.; Wozniak, D.J. Assembly and development of the Pseudomonas aeruginosa biofilm matrix. PLoS Pathog 2009, 5, e1000354. [CrossRef]

55. Renner, L.D.; Weibel, D.B. Physicochemical regulation of biofilm formation. MRS Bull. 2011, 36, 347-355. [CrossRef]

56. Boles, B.R.; Horswill, A.R. Staphylococcal biofilm disassembly. Trends Microbiol. 2011, 19, 449-455. [CrossRef]

57. Rendueles, O.; Ghigo, J.-M. Multi-species biofilms: How to avoid unfriendly neighbors. FEMS Microbiol. Rev. 2012, 36, 972-989. [CrossRef]

58. Tram, G.; Day, C.J.; Korolik, V. Bridging the gap: A role for Campylobacter jejuni biofilms. Microorganisms 2020, 8, 452. [CrossRef]

59. Whelan, M.V.; Simpson, J.C.; Cróinín, T.Ó. A novel high-content screening approach for the elucidation of Campylobacter jejuni biofilm composition and integrity. BMC Microbiol. 2021, 21, 2. [CrossRef]

60. Püning, C.; Su, Y.; Lu, X.; Gölz, G. Molecular mechanisms of Campylobacter biofilm formation and quorum sensing. In Fighting Campylobacter Infections: Towards a One Health Approach; Springer: Berlin/Heidelberg, Germany, 2021; pp. $293-319$.

61. Lim, E.S.; Kim, J.-S. Role of eptC in biofilm formation by Campylobacter jejuni NCTC11168 on polystyrene and glass surfaces. J. Microbiol. Biotechnol. 2017, 27, 1609-1616. [CrossRef] [PubMed]

62. Burnham, P.M.; Hendrixson, D.R. Campylobacter jejuni: Collective components promoting a successful enteric lifestyle. Nat. Rev. Microbiol. 2018, 16, 551-565. [CrossRef] [PubMed]

63. Guerry, P.; Poly, F.; Riddle, M.; Maue, A.C.; Chen, Y.H.; Monteiro, M.A. Campylobacter polysaccharide capsules: Virulence and vaccines. Front. Cell. Infect. Microbiol. 2012, 2, 7. [CrossRef] [PubMed]

64. Teren, M.; Michova, H.T.; Vondrakova, L.; Demnerova, K. Molecules autoinducer 2 and cjA and their impact on gene expression in Campylobacter jejuni. J. Mol. Microbiol. Biotechnol. 2018, 28, 207-215. [CrossRef]

65. Tereň, M.; Shagieva, E.; Vondrakova, L.; Viktorova, J.; Svarcova, V.; Demnerova, K.; Michova, H.T. Mutagenic strategies against luxS gene affect the early stage of biofilm formation of Campylobacter jejuni. J. Appl. Genet. 2021. [CrossRef]

66. Tischler, A.D.; Camilli, A. Cyclic diguanylate (c-di-GMP) regulates Vibrio cholerae biofilm formation. Mol. Microbiol. 2004, 53, 857-869. [CrossRef]

67. Balta, I.; Linton, M.; Pinkerton, L.; Kelly, C.; Stef, L.; Pet, I.; Stef, D.; Criste, A.; Gundogdu, O.; Corcionivoschi, N. The effect of natural antimicrobials against Campylobacter spp. and its similarities to Salmonella spp, Listeria spp., Escherichia coli, Vibrio spp., Clostridium spp. and Staphylococcus spp. Food Control 2020, 121, 107745. [CrossRef]

68. Kalogianni, A.I.; Lazou, T.; Bossis, I.; Gelasakis, A.I. Natural phenolic compounds for the control of oxidation, bacterial spoilage, and foodborne pathogens in meat. Foods 2020, 9, 794. [CrossRef]

69. Mishra, R.; Panda, A.K.; De Mandal, S.; Shakeel, M.; Bisht, S.S.; Khan, J. Natural anti-biofilm agents: Strategies to control biofilm-forming pathogens. Front. Microbiol. 2020, 11, 2640. [CrossRef] [PubMed]

70. Wagle, B.R.; Arsi, K.; Shrestha, S.; Upadhyay, A.; Upadhyaya, I.; Bhargava, K.; Donoghue, A.; Donoghue, D.J. Eugenol as an antimicrobial wash treatment reduces Campylobacter jejuni in postharvest poultry. J. Food Saf. 2019, 39, e12704. [CrossRef]

71. Upadhyaya, I.; Upadhyay, A.; Arsi, K.; Liyanage, R.; Donoghue, A.; Rath, N.; Donoghue, D. Plant-derived antimicrobial eugenol modulates Campylobacter jejun proteome and virulence critical for colonization in chickens. Poult. Sci. 2017, 96, 537.

72. Wagle, B.R.; Upadhyay, A.; Upadhyaya, I.; Shrestha, S.; Arsi, K.; Liyanage, R.; Venkitanarayanan, K.; Donoghue, D.J.; Donoghue, A.M. Trans-cinnamaldehyde, eugenol and carvacrol reduce Campylobacter jejuni biofilms and modulate expression of select genes and proteins. Front. Microbiol. 2019, 10, 1837. [CrossRef] [PubMed]

73. Yu, H.H.; Song, Y.J.; Yu, H.S.; Lee, N.K.; Paik, H.D. Investigating the antimicrobial and antibiofilm effects of cinnamaldehyde against Campylobacter spp. using cell surface characteristics. J. Food Sci. 2020, 85, 157-164. [CrossRef] [PubMed]

74. Šimunović, K.; Ramić, D.; Xu, C.; Smole Možina, S. Modulation of Campylobacter jejuni motility, adhesion to polystyrene surfaces, and invasion of INT407 cells by quorum-sensing inhibition. Microorganisms 2020, 8, 104. [CrossRef]

75. Gahamanyi, N.; Song, D.-G.; Cha, K.H.; Yoon, K.-Y.; Mboera, L.E.; Matee, M.I.; Mutangana, D.; Amachawadi, R.G.; Komba, E.V.; Pan, C.-H. Susceptibility of Campylobacter strains to selected natural products and frontline antibiotics. Antibiotics 2020, 9, 790. [CrossRef]

76. Klančnik, A.; Šimunović, K.; Sterniša, M.; Ramić, D.; Možina, S.S.; Bucar, F. Anti-adhesion activity of phytochemicals to prevent Campylobacter jejuni biofilm formation on abiotic surfaces. Phytochem. Rev. 2021, 20, 55-84. [CrossRef]

77. Salehi, B.; Upadhyay, S.; Erdogan Orhan, I.; Kumar Jugran, A.; LD Jayaweera, S.; Dias, D.A.; Sharopov, F.; Taheri, Y.; Martins, N.; Baghalpour, N. Therapeutic potential of $\alpha$-and $\beta$-pinene: A miracle gift of nature. Biomolecules 2019, 9, 738. [CrossRef]

78. Silván, J.M.; Mingo, E.; Hidalgo, M.; de Pascual-Teresa, S.; Carrascosa, A.V.; Martinez-Rodriguez, A.J. Antibacterial activity of a grape seed extract and its fractions against Campylobacter spp. Food Control 2013, 29, 25-31. [CrossRef]

79. Castillo, S.; Heredia, N.; Arechiga-Carvajal, E.; García, S. Citrus extracts as inhibitors of quorum sensing, biofilm formation and motility of Campylobacter jejuni. Food Biotechnol. 2014, 28, 106-122. [CrossRef]

80. Bezek, K.; Kurinčič, M.; Knauder, E.; Klančnik, A.; Raspor, P.; Bucar, F.; Smole Možina, S. Attenuation of adhesion, biofilm formation and quorum sensing of Campylobacter jejuni by Euodia ruticarpa. Phytother. Res. 2016, 30, 1527-1532. [CrossRef] [PubMed] 
81. Wagle, B.R.; Donoghue, A.M.; Jesudhasan, P.R. Select phytochemicals reduce Campylobacter jejuni in postharvest poultry and modulate the virulence attributes of C. jejuni. Front. Microbiol. 2021, 2270. [CrossRef]

82. Lu, X.; Samuelson, D.R.; Rasco, B.A.; Konkel, M.E. Antimicrobial effect of diallyl sulphide on Campylobacter jejuni biofilms. J. Antimicrob. Chemother. 2012, 67, 1915-1926. [CrossRef] [PubMed]

83. Castillo, S.; Heredia, N.; García, S. 2 (5H)-Furanone, epigallocatechin gallate, and a citric-based disinfectant disturb quorumsensing activity and reduce motility and biofilm formation of Campylobacter jejuni. Folia Microbiol. 2015, 60, 89-95. [CrossRef] [PubMed]

84. Roila, R.; Ranucci, D.; Valiani, A.; Galarini, R.; Servili, M.; Branciari, R. Antimicrobial and anti-biofilm activity of olive oil by-products against Campylobacter spp. isolated from chicken meat. Acta Sci. Pol. Technol. Aliment. 2019, 18, 43-52. [PubMed]

85. Duarte, A.; Alves, A.C.; Ferreira, S.; Silva, F.; Domingues, F.C. Resveratrol inclusion complexes: Antibacterial and anti-biofilm activity against Campylobacter spp. and Arcobacter butzleri. Food Res. Int. 2015, 77, 244-250. [CrossRef]

86. Romeo, T. When the party is over: A signal for dispersal of Pseudomonas aeruginosa biofilms. J. Bacteriol. 2006, 188, 7325-7327. [CrossRef] [PubMed]

87. McDougald, D.; Rice, S.A.; Barraud, N.; Steinberg, P.D.; Kjelleberg, S. Should we stay or should we go: Mechanisms and ecological consequences for biofilm dispersal. Nat. Rev. Microbiol. 2012, 10, 39-50. [CrossRef] [PubMed]

88. Silveira, V.A.I.; Nishio, E.K.; Freitas, C.A.; Amador, I.R.; Kobayashi, R.K.; Caretta, T.; Macedo, F.; Celligoi, M.A.P. Production and antimicrobial activity of sophorolipid against Clostridium perfringens and Campylobacter jejuni and their additive interaction with lactic acid. Biocatal. Agric. Biotechnol. 2019, 21, 101287. [CrossRef]

89. Asare, P.T.; Zurfluh, K.; Greppi, A.; Lynch, D.; Schwab, C.; Stephan, R.; Lacroix, C. Reuterin demonstrates potent antimicrobial activity against a broad panel of human and poultry meat Campylobacter spp. isolates. Microorganisms 2020, 8, 78. [CrossRef] [PubMed]

90. Svetoch, E.A.; Eruslanov, B.V.; Perelygin, V.V.; Mitsevich, E.V.; Mitsevich, I.P.; Borzenkov, V.N.; Levchuk, V.P.; Svetoch, O.E.; Kovalev, Y.N.; Stepanshin, Y.G. Diverse antimicrobial killing by Enterococcus faecium E 50-52 bacteriocin. J. Agric. Food Chem. 2008, 56, 1942-1948. [CrossRef] [PubMed]

91. Micciche, A.; Rothrock Jr, M.J.; Yang, Y.; Ricke, S.C. Essential oils as an intervention strategy to reduce Campylobacter in poultry production: A review. Front. Microbiol. 2019, 10, 1058. [CrossRef] [PubMed]

92. Lu, L.; Hu, W.; Tian, Z.; Yuan, D.; Yi, G.; Zhou, Y.; Cheng, Q.; Zhu, J.; Li, M. Developing natural products as potential anti-biofilm agents. Chin. Med. 2019, 14, 11. [CrossRef]

93. Abd Rashed, A.; Rathi, D.-N.G.; Ahmad Nasir, N.A.H.; Abd Rahman, A.Z. Antifungal properties of essential oils and their compounds for application in skin fungal infections: Conventional and nonconventional approaches. Molecules 2021, $26,1093$. [CrossRef]

94. Mucha, W.; Witkowska, D. The applicability of essential oils in different stages of production of animal-based foods. Molecules 2021, 26, 3798. [CrossRef]

95. Kurekci, C.; Padmanabha, J.; Bishop-Hurley, S.L.; Hassan, E.; Al Jassim, R.A.; McSweeney, C.S. Antimicrobial activity of essential oils and five terpenoid compounds against Campylobacter jejuni in pure and mixed culture experiments. Int. J. Food Microbiol. 2013, 166, 450-457. [CrossRef]

96. De Oliveira, M.M.M.; Brugnera, D.F.; das Graças Cardoso, M.; Alves, E.; Piccoli, R.H. Disinfectant action of Cymbopogon sp. essential oils in different phases of biofilm formation by Listeria monocytogenes on stainless steel surface. Food Control 2010, 21, 549-553. [CrossRef]

97. Puškárová, A.; Bučková, M.; Kraková, L.; Pangallo, D.; Kozics, K. The antibacterial and antifungal activity of six essential oils and their cyto/genotoxicity to human HEL 12469 cells. Sci. Rep. 2017, 7, 8211. [CrossRef] [PubMed]

98. Valeriano, C.; De Oliveira, T.L.C.; De Carvalho, S.M.; das Graças Cardoso, M.; Alves, E.; Piccoli, R.H. The sanitizing action of essential oil-based solutions against Salmonella enterica serotype Enteritidis S64 biofilm formation on AISI 304 stainless steel. Food Control 2012, 25, 673-677. [CrossRef]

99. Zhai, H.; Liu, H.; Wang, S.; Wu, J.; Kluenter, A.-M. Potential of essential oils for poultry and pigs. Anim. Nutr 2018, 4, 179-186. [CrossRef] [PubMed]

100. Kirkpinar, F.; Ünlü, H.; Serdaroğlu, M.; Turp, G. Effects of dietary oregano and garlic essential oils on carcass characteristics, meat composition, colour, pH and sensory quality of broiler meat. Br. Poult. Sci. 2014, 55, 157-166. [CrossRef] [PubMed]

101. Witkowska, D.; Sowińska, J. The effectiveness of peppermint and thyme essential oil mist in reducing bacterial contamination in broiler houses. Poult. Sci. 2013, 92, 2834-2843. [CrossRef] [PubMed]

102. Topa, S.H.; Subramoni, S.; Palombo, E.A.; Kingshott, P.; Rice, S.A.; Blackall, L.L. Cinnamaldehyde disrupts biofilm formation and swarming motility of Pseudomonas aeruginosa. Microbiology 2018, 164, 1087-1097. [CrossRef] [PubMed]

103. He, Z.; Huang, Z.; Jiang, W.; Zhou, W. Antimicrobial activity of cinnamaldehyde on Streptococcus mutans biofilms. Front. Microbiol. 2019, 10, 2241. [CrossRef] [PubMed]

104. Trevisan, D.A.C.; Silva, A.F.D.; Negri, M.; Abreu, B.A.D.; Machinski, M.; Patussi, E.V.; Campanerut-Sá, P.A.Z.; Mikcha, J.M.G. Antibacterial and antibiofilm activity of carvacrol against Salmonella enterica serotype Typhimurium. Braz. J. Pharm. Sci. 2018, 54. [CrossRef]

105. Upadhyay, A.; Upadhyaya, I.; Kollanoor-Johny, A.; Venkitanarayanan, K. Antibiofilm effect of plant derived antimicrobials on Listeria monocytogenes. Food Microbiol. 2013, 36, 79-89. [CrossRef] [PubMed] 
106. Wagle, B.; Donoghue, A.; Shrestha, S.; Upadhyaya, I.; Arsi, K.; Gupta, A.; Liyanage, R.; Rath, N.; Donoghue, D.; Upadhyay, A. Carvacrol attenuates Campylobacter jejuni colonization factors and proteome critical for persistence in the chicken gut. Poult. Sci. 2020, 99, 4566-4577. [CrossRef] [PubMed]

107. Johny, A.K.; Darre, M.; Donoghue, A.; Donoghue, D.; Venkitanarayanan, K. Antibacterial effect of trans-cinnamaldehyde, eugenol, carvacrol, and thymol on Salmonella Enteritidis and Campylobacter jejuni in chicken cecal contents in vitro. J. Appl. Poult. Res. 2010, 19, 237-244. [CrossRef]

108. Kelly, C.; Gundogdu, O.; Pircalabioru, G.; Cean, A.; Scates, P.; Linton, M.; Pinkerton, L.; Magowan, E.; Stef, L.; Simiz, E. The in vitro and in vivo effect of carvacrol in preventing Campylobacter infection, colonization and in improving productivity of chicken broilers. Foodborne Pathog. Dis. 2017, 14, 341-349. [CrossRef] [PubMed]

109. Allaoua, M.; Etienne, P.; Noirot, V.; Carayon, J.L.; Tene, N.; Bonnafé, E.; Treilhou, M. Pharmacokinetic and antimicrobial activity of a new carvacrol-based product against a human pathogen, Campylobacter jejuni. J. Appl. Microbiol. 2018, 125, 1162-1174. [CrossRef]

110. Mousavi, S.; Schmidt, A.-M.; Escher, U.; Kittler, S.; Kehrenberg, C.; Thunhorst, E.; Bereswill, S.; Heimesaat, M.M. Carvacrol ameliorates acute campylobacteriosis in a clinical murine infection model. Gut Pathog. 2020, 12, 2. [CrossRef] [PubMed]

111. Szott, V.; Reichelt, B.; Alter, T.; Friese, A.; Roesler, U. In vivo efficacy of carvacrol on Campylobacter jejuni prevalence in broiler chickens during an entire fattening period. Eur. J. Microbiol. Immunol. 2020, 10, 131-138. [CrossRef] [PubMed]

112. Simunovic, K.; Bucar, F.; Klancnik, A.; Pompei, F.; Paparella, A.; Mozina, S.S. In vitro effect of the common culinary herb winter savory (Satureja montana) against the infamous food pathogen Campylobacter jejuni. Foods 2020, 9, 537. [CrossRef] [PubMed]

113. Arsi, K.; Donoghue, A.; Venkitanarayanan, K.; Kollanoor-Johny, A.; Fanatico, A.; Blore, P.; Donoghue, D. The efficacy of the natural plant extracts, thymol and carvacrol against Campylobacter colonization in broiler chickens. J. Food Saf. 2014, 34, 321-325. [CrossRef]

114. Robyn, J.; Rasschaert, G.; Pasmans, F.; Heyndrickx, M. Thermotolerant Campylobacter during broiler rearing: Risk factors and intervention. Compr. Rev. Food Sci. Food Saf. 2015, 14, 81-105. [CrossRef] [PubMed]

115. Hashemipour, H.; Kermanshahi, H.; Golian, A.; Veldkamp, T. Effect of thymol and carvacrol feed supplementation on performance, antioxidant enzyme activities, fatty acid composition, digestive enzyme activities, and immune response in broiler chickens. Poult. Sci. 2013, 92, 2059-2069. [CrossRef]

116. Chowdhury, S.; Mandal, G.P.; Patra, A.K. Different essential oils in diets of chickens: Growth performance, nutrient utilisation, nitrogen excretion, carcass traits and chemical composition of meat. Anim. Feed Sci. Technol. 2018, 236, 86-97. [CrossRef]

117. Santini, C.; Baffoni, L.; Gaggia, F.; Granata, M.; Gasbarri, R.; Di Gioia, D.; Biavati, B. Characterization of probiotic strains: An application as feed additives in poultry against Campylobacter jejuni. Int. J. Food Microbiol. 2010, 141, S98-S108. [CrossRef] [PubMed]

118. Minami, M.; Kita, M.; Nakaya, T.; Yamamoto, T.; Kuriyama, H.; Imanishi, J. The inhibitory effect of essential oils on herpes simplex virus type-1 replication in vitro. Microbiol. Immunol. 2003, 47, 681-684. [CrossRef]

119. Wińska, K.; Mączka, W.; Łyczko, J.; Grabarczyk, M.; Czubaszek, A.; Szumny, A. Essential oils as antimicrobial agents-Myth or real alternative? Molecules 2019, 24, 2130. [CrossRef] [PubMed]

120. Roller, S.; Ernest, N.; Buckle, J. The antimicrobial activity of high-necrodane and other lavender oils on methicillin-sensitive and-resistant Staphylococcus aureus (MSSA and MRSA). J. Altern. Complement. Med. 2009, 15, 275-279. [CrossRef] [PubMed]

121. Adaszyńska-Skwirzyńska, M.; Dzięcioł, M. Comparison of phenolic acids and flavonoids contents in various cultivars and parts of common lavender (Lavandula angustifolia) derived from Poland. Nat. Prod. Res. 2017, 31, 2575-2580. [CrossRef] [PubMed]

122. Adaszyńska-Skwirzyńska, M.; Szczerbińska, D. The antimicrobial activity of lavender essential oil (Lavandula angustifolia) and its influence on the production performance of broiler chickens. J. Anim. Physiol. Anim. Nutr. 2018, 102, 1020-1025. [CrossRef] [PubMed]

123. Císarová, M.; Tančinová, D.; Medo, J. Antifungal activity of lemon, eucalyptus, thyme, oregano, sage and lavender essential oils against Aspergillus niger and Aspergillus tubingensis isolated from grapes. Potravinarstvo 2016, 10, 83-88.

124. Ramić, D.; Bucar, F.; Kunej, U.; Dogša, I.; Klančnik, A.; Smole Možina, S. Anti-biofilm potential of Lavandula preparations against Campylobacter jejuni. Appl. Environ. Microbiol. 2021, 87, e01099-21. [CrossRef] [PubMed]

125. Klančnik, A.; Zorko, Š.; Toplak, N.; Kovač, M.; Bucar, F.; Jeršek, B.; Smole Možina, S. Antiadhesion activity of juniper (Juniperus communis L.) preparations against Campylobacter jejuni evaluated with PCR-based methods. Phytother Res. 2018, 32, 542-550. [CrossRef]

126. Sharifi-Rad, J.; Sureda, A.; Tenore, G.C.; Daglia, M.; Sharifi-Rad, M.; Valussi, M.; Tundis, R.; Sharifi-Rad, M.; Loizzo, M.R.; Ademiluyi, A.O. Biological activities of essential oils: From plant chemoecology to traditional healing systems. Molecules 2017, 22, 70. [CrossRef]

127. Khalifaev, P.D.; Sharopov, F.S.; Safomuddin, A.; Numonov, S.; Bakri, M.; Habasi, M.; Aisa, H.A.; Setzer, W.N. Chemical composition of the essential oil from the roots of Ferula kuhistanica growing wild in Tajikistan. Nat. Prod. Commun. 2018, 13, 1934578X1801300226. [CrossRef]

128. Sharopov, F.; Satyal, P.; Wink, M. Composition of the essential oil of Ferula clematidifolia. Chem. Nat. Compd. 2016, 52, 518-519. [CrossRef]

129. Šimunović, K.; Sahin, O.; Kovač, J.; Shen, Z.; Klančnik, A.; Zhang, Q.; Smole Možina, S. (-)- $\alpha$-Pinene reduces quorum sensing and Campylobacter jejuni colonization in broiler chickens. PLoS ONE 2020, 15, e0230423. [CrossRef] [PubMed] 
130. Bora, H.; Kamle, M.; Mahato, D.K.; Tiwari, P.; Kumar, P. Citrus essential oils (CEOs) and their applications in food: An overview. Plants 2020, 9, 357. [CrossRef] [PubMed]

131. Sarma, R.; Khanikor, B.; Mahanta, S. Essential oil from Citrus grandis (Sapindales: Rutaceae) as insecticide against Aedes aegypti (L)(Diptera: Culicidae). Int. J. Mosq. Res. 2017, 4, 88-92.

132. Caputo, L.; Quintieri, L.; Cavalluzzi, M.M.; Lentini, G.; Habtemariam, S. Antimicrobial and antibiofilm activities of citrus water-extracts obtained by microwave-assisted and conventional methods. Biomedicines 2018, 6, 70. [CrossRef] [PubMed]

133. Zubair, M. Antimicrobial and anti-Biofilm activities of Citrus sinensis and Moringa oleifera against the pathogenic Pseudomonas aeruginosa and Staphylococcus aureus. Cureus 2020, 12, e12337.

134. Dosoky, N.S.; Setzer, W.N. Biological activities and safety of Citrus spp. essential oils. Int. J. Mol. Sci. 2018, 19, 1966. [CrossRef]

135. Hassan, Y.I.; Kosir, V.; Yin, X.; Ross, K.; Diarra, M.S. Grape pomace as a promising antimicrobial alternative in feed: A critical review. J. Agric. Food Chem. 2019, 67, 9705-9718. [CrossRef] [PubMed]

136. Song, Y.J.; Yu, H.H.; Kim, Y.J.; Lee, N.-K.; Paik, H.-D. Anti-biofilm activity of grapefruit seed extract against Staphylococcus aureus and Escherichia coli. J. Microbiol. Biotechnol. 2019, 29, 1177-1183. [CrossRef] [PubMed]

137. Han, H.-W.; Kwak, J.-H.; Jang, T.-S.; Knowles, J.C.; Kim, H.-W.; Lee, H.-H.; Lee, J.-H. Grapefruit seed extract as a natural derived antibacterial substance against multidrug-resistant bacteria. Antibiotics 2021, 10, 85. [CrossRef]

138. Klančnik, A.; Šikić Pogačar, M.; Trošt, K.; Tušek Žnidarič, M.; Mozetič Vodopivec, B.; Smole Možina, S. Anti-Campylobacter activity of resveratrol and an extract from waste Pinot noir grape skins and seeds, and resistance of Campylobacter jejuni planktonic and biofilm cells, mediated via the Cme ABC efflux pump. J. Appl. Microbiol. 2017, 122, 65-77. [CrossRef]

139. Abu Hafsa, S.; Ibrahim, S. Effect of dietary polyphenol-rich grape seed on growth performance, antioxidant capacity and ileal microflora in broiler chicks. J. Anim. Physiol. Anim. Nutr. 2018, 102, 268-275. [CrossRef] [PubMed]

140. Huang, Q.; Liu, X.; Zhao, G.; Hu, T.; Wang, Y. Potential and challenges of tannins as an alternative to in-feed antibiotics for farm animal production. Anim. Nutr. 2018, 4, 137-150. [CrossRef]

141. Pastrana-Bonilla, E.; Akoh, C.C.; Sellappan, S.; Krewer, G. Phenolic content and antioxidant capacity of muscadine grapes. J. Agric. Food Chem. 2003, 51, 5497-5503. [CrossRef] [PubMed]

142. Serio, A.; Chaves-López, C.; Martuscelli, M.; Mazzarrino, G.; Di Mattia, C.; Paparella, A. Application of Central Composite Design to evaluate the antilisterial activity of hydro-alcohol berry extract of Myrtus communis L. LWT-Food Sci. Technol. 2014, 58, 116-123. [CrossRef]

143. Valle, D.L., Jr.; Cabrera, E.C.; Puzon, J.J.M.; Rivera, W.L. Antimicrobial activities of methanol, ethanol and supercritical CO 2 extracts of Philippine Piper betle L. on clinical isolates of gram positive and gram negative bacteria with transferable multiple drug resistance. PLoS ONE 2016, 11, e0146349. [CrossRef] [PubMed]

144. Pan, X.; Bligh, S.A.; Smith, E. Quinolone alkaloids from Fructus Euodiae show activity against methicillin-resistant Staphylococcus aureus. Phytother. Res. 2014, 28, 305-307. [CrossRef] [PubMed]

145. Wang, X.-X.; Zan, K.; Shi, S.-P.; Zeng, K.-W.; Jiang, Y.; Guan, Y.; Xiao, C.-L.; Gao, H.-Y.; Wu, L.-J.; Tu, P.-F. Quinolone alkaloids with antibacterial and cytotoxic activities from the fruits of Evodia rutaecarpa. Fitoterapia 2013, 89, 1-7. [CrossRef]

146. Akiba, M.; Lin, J.; Barton, Y.-W.; Zhang, Q. Interaction of CmeABC and CmeDEF in conferring antimicrobial resistance and maintaining cell viability in Campylobacter jejuni. J. Antimicrob. Chemother. 2006, 57, 52-60. [CrossRef]

147. Pérez-Jiménez, J.; Neveu, V.; Vos, F.; Scalbert, A. Identification of the 100 richest dietary sources of polyphenols: An application of the Phenol-Explorer database. Eur. J. Clin. Nutr. 2010, 64, S112-S120. [CrossRef] [PubMed]

148. Zhang, J.; Rui, X.; Wang, L.; Guan, Y.; Sun, X.; Dong, M. Polyphenolic extract from Rosa rugosa tea inhibits bacterial quorum sensing and biofilm formation. Food Control 2014, 42, 125-131. [CrossRef]

149. Nassima, B.; Nassima, B.; Riadh, K. Antimicrobial and antibiofilm activities of phenolic compounds extracted from Populus nigra and Populus alba buds (Algeria). Braz. J. Pharm. Sci. 2019, 55. [CrossRef]

150. Sánchez, M.C.; Ribeiro-Vidal, H.; Esteban-Fernández, A.; Bartolomé, B.; Figuero, E.; Moreno-Arribas, M.V.; Sanz, M.; Herrera, D. Antimicrobial activity of red wine and oenological extracts against periodontal pathogens in a validated oral biofilm model. $B M C$ Complement. Altern. Med. 2019, 19, 145. [CrossRef] [PubMed]

151. Kharouf, N.; Haikel, Y.; Ball, V. Polyphenols in Dental Applications. Bioengineering 2020, 7, 72. [CrossRef]

152. Philip, N.; Leishman, S.J.; Bandara, H.; Walsh, L.J. Polyphenol-rich cranberry extracts modulate virulence of Streptococcus mutans-Candida albicans biofilms implicated in the pathogenesis of early childhood caries. Pediatr. Dent. 2019, 41, 56-62.

153. Philip, N.; Bandara, H.; Leishman, S.J.; Walsh, L.J. Inhibitory effects of fruit berry extracts on Streptococcus mutans biofilms. Eur. J. Oral Sci. 2019, 127, 122-129. [CrossRef] [PubMed]

154. Oh, E.; Jeon, B. Synergistic anti-Campylobacter jejuni activity of fluoroquinolone and macrolide antibiotics with phenolic compounds. Front. Microbiol. 2015, 6, 1129. [CrossRef]

155. Lorenzo, J.M.; Munekata, P.E.S. Phenolic compounds of green tea: Health benefits and technological application in food. Asian Pac. J. Trop. Biomed. 2016, 6, 709-719. [CrossRef]

156. Zhao, C.-N.; Tang, G.-Y.; Cao, S.-Y.; Xu, X.-Y.; Gan, R.-Y.; Liu, Q.; Mao, Q.-Q.; Shang, A.; Li, H.-B. Phenolic profiles and antioxidant activities of 30 tea infusions from green, black, oolong, white, yellow and dark teas. Antioxidants 2019, 8, 215. [CrossRef] [PubMed]

157. Klepacka, J.; Tońska, E.; Rafałowski, R.; Czarnowska-Kujawska, M.; Opara, B. Tea as a source of biologically active compounds in the human diet. Molecules 2021, 26, 1487. [CrossRef] 
158. Biswas, A.H.; Wakita, M. Effect of dietary Japanese green tea powder supplementation on feed utilization and carcass profiles in broilers. J. Poult. Sci. 2001, 38, 50-57. [CrossRef]

159. Chen, X.; Zhu, W.; Liu, X.; Li, T.; Geng, Z.; Wan, X. The growth performance, meat quality, and gut bacteria of broilers raised with or without antibiotics and green tea powder. J. Appl. Poult. Res. 2019, 28, 712-721. [CrossRef]

160. Vestergaard, M.; Ingmer, H. Antibacterial and antifungal properties of resveratrol. Int. J. Antimicrob. Agents. 2019, 53, 716-723. [CrossRef]

161. Andrade, M.; Malheiro, J.; Borges, F.; Saavedra, M.J.; Simões, M. The potential of phytochemical products in biofilm control. In Recent Trends in Biofilm Science and Technology; Elsevier: Amsterdam, The Netherlands, 2020; pp. 273-293.

162. Lu, X.; Rasco, B.A.; Kang, D.H.; Jabal, J.M.; Aston, D.E.; Konkel, M.E. Infrared and Raman spectroscopic studies of the antimicrobial effects of garlic concentrates and diallyl constituents on foodborne pathogens. Anal. Chem. 2011, 83, 4137-4146. [CrossRef]

163. Bhatwalkar, S.B.; Mondal, R.; Krishna, S.B.N.; Adam, J.K.; Govender, P.; Anupam, R. Antibacterial Properties of Organosulfur Compounds of Garlic (Allium sativum). Front. Microbiol. 2021, 12, 613077. [CrossRef] [PubMed]

164. Chen, S.H.; Fegan, N.; Kocharunchitt, C.; Bowman, J.P.; Duffy, L.L. Effect of peracetic acid on Campylobacter in food matrices mimicking commercial poultry processing. Food Control 2020, 113, 107185. [CrossRef]

165. Li, J.; Koh, J.-J.; Liu, S.; Lakshminarayanan, R.; Verma, C.S.; Beuerman, R.W. Membrane active antimicrobial peptides: Translating mechanistic insights to design. Front. Neurosci. 2017, 11, 73. [CrossRef]

166. Tam, J.P.; Wang, S.; Wong, K.H.; Tan, W.L. Antimicrobial peptides from plants. Pharmaceuticals 2015, 8, 711-757. [CrossRef]

167. Campos, M.L.; de Souza, C.M.; de Oliveira, K.B.S.; Dias, S.C.; Franco, O.L. The role of antimicrobial peptides in plant immunity. J. Exp. Bot. 2018, 69, 4997-5011. [CrossRef]

168. Talukdar, P.K.; Turner, K.L.; Crockett, T.M.; Lu, X.; Morris, C.F.; Konkel, M.E. Inhibitory effect of puroindoline peptides on Campylobacter jejuni growth and biofilm formation. Front. Microbiol. 2021, 12, 702762. [CrossRef] [PubMed]

169. Morris, C.F. The antimicrobial properties of the puroindolines, a review. World J. Microbiol. Biotechnol. 2019, 35, 86. [CrossRef]

170. Lv, A.; Li, C.; Tian, P.; Yuan, W.; Zhang, S.; Lv, Y.; Hu, Y. Expression and purification of recombinant puroindoline A protein in Escherichia coli and its antifungal effect against Aspergillus flavus. Appl. Microbiol. Biotechnol. 2019, 103, 9515-9527. [CrossRef]

171. Shagaghi, N.; Alfred, R.L.; Clayton, A.H.; Palombo, E.A.; Bhave, M. Anti-biofilm and sporicidal activity of peptides based on wheat puroindoline and barley hordoindoline proteins. J. Pept. Sci. 2016, 22, 492-500. [CrossRef]

172. Alfred, R.L.; Palombo, E.A.; Panozzo, J.F.; Bhave, M. The antimicrobial domains of wheat puroindolines are cell-penetrating peptides with possible intracellular mechanisms of action. PLOS ONE 2013, 8, e75488. [CrossRef]

173. Rizzo, L.; Fraschetti, S.; Alifano, P.; Tredici, M.S.; Stabili, L. Association of Vibrio community with the atlantic mediterranean invasive alga Caulerpa cylindracea. J. Exp. Mar. Biol. Ecol. 2016, 475, 129-136. [CrossRef]

174. Abu-Ghannam, N.; Rajauria, G. Antimicrobial activity of compounds isolated from algae. In Functional Ingredients from Algae for Foods and Nutraceuticals; Elsevier: Amsterdam, The Netherlands, 2013; pp. 287-306.

175. Shannon, E.; Abu-Ghannam, N. Antibacterial derivatives of marine algae: An overview of pharmacological mechanisms and applications. Mar. Drugs 2016, 14, 81. [CrossRef]

176. Galie, S.; García-Gutiérrez, C.; Miguélez, E.M.; Villar, C.J.; Lombó, F. Biofilms in the food industry: Health aspects and control methods. Front. Microbiol. 2018, 9, 898. [CrossRef]

177. Carroll, A.R.; Copp, B.R.; Davis, R.A.; Keyzers, R.A.; Prinsep, M.R. Marine natural products. Nat. Prod. Rep. 2019, 36, 122-173. [CrossRef]

178. Mayer, A.; Rodriguez, A.; Taglialatela-Scafati, O.; Fusetani, N. Marine compounds with antibacterial, antidiabetic, antifungal, anti-inflammatory, antiprotozoal, antituberculosis, and antiviral activities; affecting the immune and nervous systems, and other miscellaneous mechanisms of action. Mar. Drugs 2003, 11, 2510-2573. [CrossRef]

179. Cermak, L.; Pražáková, Š.; Marounek, M.; Skrivan, M.; Skrivanová, E. Effect of green alga Planktochlorella nurekis on selected bacteria revealed antibacterial activity in vitro. Czech J. Anim. Sci. 2015, 60, 427-435. [CrossRef]

180. Coudert, E.; Baéza, E.; Berri, C. Use of algae in poultry production: A review. Worlds Poult Sci. J. 2020, 76, 767-786. [CrossRef]

181. Brandenburg, K.S.; Rodriguez, K.J.; McAnulty, J.F.; Murphy, C.J.; Abbott, N.L.; Schurr, M.J.; Czuprynski, C.J. Tryptophan inhibits biofilm formation by Pseudomonas aeruginosa. Antimicrob. Agents Chemother. 2013, 57, 1921-1925. [CrossRef]

182. Leiman, S.A.; May, J.M.; Lebar, M.D.; Kahne, D.; Kolter, R.; Losick, R. d-Amino acids indirectly inhibit biofilm formation in Bacillus subtilis by interfering with protein synthesis. J. Bacteriol. 2013, 195, 5391-5395. [CrossRef]

183. Kolodkin-Gal, I.; Cao, S.; Chai, L.; Bottcher, T.; Kolter, R.; Clardy, J.; Losick, R. A self-produced trigger for biofilm disassembly that targets exopolysaccharide. Cell 2012, 149, 684-692. [CrossRef]

184. Xu, H.; Liu, Y. Reduced microbial attachment by d-amino acid-inhibited AI-2 and EPS production. Water Res. 2011, 45, 5796-5804. [CrossRef]

185. Sanchez, C.J.; Akers, K.S.; Romano, D.R.; Woodbury, R.L.; Hardy, S.K.; Murray, C.K.; Wenke, J.C. d-Amino acids enhance the activity of antimicrobials against biofilms of clinical wound isolates of Staphylococcus aureus and Pseudomonas aeruginosa. Antimicrob. Agents Chemother. 2014, 58, 4353-4361. [CrossRef]

186. Barzegari, A.; Kheyrolahzadeh, K.; Khatibi, S.M.H.; Sharifi, S.; Memar, M.Y.; Vahed, S.Z. The battle of probiotics and their derivatives against biofilms. Infect. Drug Resist. 2020, 13, 659. [CrossRef] 
187. Cristofori, F.; Dargenio, V.N.; Dargenio, C.; Miniello, V.L.; Barone, M.; Francavilla, R. Anti-inflammatory and immunomodulatory effects of probiotics in gut inflammation: A door to the body. Front. Immunol. 2021, 12, 178. [CrossRef]

188. Hoang, K.; Stern, N.J.; Lin, J. Development and stability of bacteriocin resistance in Campylobacter spp. J. Appl. Microbiol. 2011, 111, 1544-1550. [CrossRef] [PubMed]

189. Teame, T.; Wang, A.; Xie, M.; Zhang, Z.; Yang, Y.; Ding, Q.; Gao, C.; Olsen, R.E.; Ran, C.; Zhou, Z. Paraprobiotics and postbiotics of probiotic Lactobacilli, their positive effects on the host and action mechanisms: A review. Front. Nutr. 2020, 7, 570344. [CrossRef] [PubMed]

190. Stern, N.; Svetoch, E.; Eruslanov, B.; Perelygin, V.; Mitsevich, E.; Mitsevich, I.; Pokhilenko, V.; Levchuk, V.; Svetoch, O.; Seal, B. Isolation of a Lactobacillus salivarius strain and purification of its bacteriocin, which is inhibitory to Campylobacter jejuni in the chicken gastrointestinal system. Antimicrob. Agents Chemother. 2006, 50, 3111-3116. [CrossRef] [PubMed]

191. Cleusix, V.; Lacroix, C.; Vollenweider, S.; Duboux, M.; Le Blay, G. Inhibitory activity spectrum of reuterin produced by Lactobacillus reuteri against intestinal bacteria. BMC Microbiol. 2007, 7, 101. [CrossRef]

192. Stevens, M.; Vollenweider, S.; Lacroix, C.; Zurich, E. The potential of reuterin produced by Lactobacillus reuteri as a broad spectrum preservative in food. In Protective Cultures, Antimicrobial Metabolites and Bacteriophages for Food and Beverage Biopreservation; Elsevier: Amsterdam, The Netherlands, 2011; pp. 129-160.

193. Engels, C.; Schwab, C.; Zhang, J.; Stevens, M.J.; Bieri, C.; Ebert, M.-O.; McNeill, K.; Sturla, S.J.; Lacroix, C. Acrolein contributes strongly to antimicrobial and heterocyclic amine transformation activities of reuterin. Sci. Rep. 2016, 6, 36246. [CrossRef]

194. Fujiwara, N.; Murakami, K.; Nakao, M.; Toguchi, M.; Yumoto, H.; Hirota, K.; Matsuo, T.; Sano, S.; Ozaki, K.; Miyake, Y. Antibacterial and Antibiofilm Effects of Reuterin-Related Compounds to Periodontopathic Bacteria. J. Oral Health Biosci. 2017, 30, 8-17.

195. Topal, E.; Ozdogan, M. Effects of glycerol on the growth performance, internal organ weights, and drumstick muscle of broilers. J. Appl. Poult. Res. 2013, 22, 146-151. [CrossRef]

196. Shu, Q.; Lou, H.; Wei, T.; Liu, X.; Chen, Q. Contributions of glycolipid biosurfactants and glycolipid-modified materials to antimicrobial strategy: A review. Pharmaceutics 2021, 13, 227. [CrossRef]

197. Zhang, X.; Ashby, R.; Solaiman, D.K.; Uknalis, J.; Fan, X. Inactivation of Salmonella spp. and Listeria spp. by palmitic, stearic, and oleic acid sophorolipids and thiamine dilauryl sulfate. Front. Microbiol. 2016, 7, 2076. [CrossRef]

198. Zhang, X.; Ashby, R.D.; Solaiman, D.K.; Liu, Y.; Fan, X. Antimicrobial activity and inactivation mechanism of lactonic and free acid sophorolipids against Escherichia coli O157: H7. Biocatal. Agric. Biotechnol. 2017, 11, 176-182. [CrossRef]

199. Silveira, V.A.I.; Freitas, C.; Celligoi, M. Antimicrobial applications of sophorolipid from Candida bombicola: A promising alternative to conventional drugs. J. Appl. Biol. Biotechnol. 2018, 6, 87-90.

200. Silveira, V.A.I.; Marim, B.M.; Hipolito, A.; Gonçalves, M.C.; Mali, S.; Kobayashi, R.K.T.; Celligoi, M.A.P.C. Characterization and antimicrobial properties of bioactive packaging films based on polylactic acid-sophorolipid for the control of foodborne pathogens. Food Packag. Shelf Life 2020, 26, 100591. [CrossRef]

201. Valotteau, C.; Banat, I.M.; Mitchell, C.A.; Lydon, H.; Marchant, R.; Babonneau, F.; Pradier, C.-M.; Baccile, N.; Humblot, V. Antibacterial properties of sophorolipid-modified gold surfaces against Gram positive and Gram negative pathogens. Colloids Surf. B Biointerfaces 2017, 157, 325-334. [CrossRef]

202. Cil, G.I.; Ozdemir, H.; Onaran, B.; Cengiz, G.; Erdi, S. Effect of lactic acid and steam treatments on Campylobacter jejuni on chicken skin. Emir. J. Food Agric. 2019, 143-147.

203. Liu, A.; Peng, Z.; Zou, L.; Zhou, K.; Ao, X.; He, L.; Chen, S.; Liu, S. The effects of lactic acid-based spray washing on bacterial profile and quality of chicken carcasses. Food Control 2016, 60, 615-620. [CrossRef]

204. Nagel, G.M.; Bauermeister, L.; Bratcher, C.; Singh, M.; McKee, S. Salmonella and Campylobacter reduction and quality characteristics of poultry carcasses treated with various antimicrobials in a post-chill immersion tank. Int. J. Food Microbiol. 2013, 165, 281-286. [CrossRef] [PubMed] 